
\begin{abstract}
pln IJMB International Journal of Management and Business Vol. 1 No. 1 (2020) 31-36 ISSN Media Elektronik: 2722-4953

\section{Pengaruh Motivasi Kerja Terhadap Kinerja Pegawai}

\author{
Kelik Purwanto \\ Manajemen, Fakultas Hukum dan Ekonomi Bisnis, Universitas Dharmas Indonesia \\ kelikpurwanto@undhari.ac.id
}

Abstract

Research was conducted with to determine extentthe influence work motivation simultaneously on employee performance. How far the influence work motivation partially employee performance. This type research conclusive research that answering problem that requires solution using quantitative descriptive approach. Analysis Techniques with Validity Test, Instrument Reliability Test, Descriptive statistical analysis, Hypothesis Test, Linearity Test, Multiple Linear Regression Analysis.Motivation together has positive effect employee performance based the Summary model above that the coefficient $R$ is (0.730) and the Adjusted $R$ Square coefficient value 0.510 which means that there is influence of work motivation is (51\%) and the rest (49\%) in influenced other variables not examined To see whether work motivation has a positive and significant effect on employee performance, it can be seen that the value $f_{-}$count 23.531 greater than $f_{-}$table of 2.75, which 23.531> 2.75 with significance level of 0.000. Work motivation has positive and significant effect on employee performance seen in the coefficient table, value of 2.034 is greater than t_table 1.99897 with a significant level smaller than alpha $(0.046<0.05)$, then Ho is rejected and accepted Conclusion Motivation Variable $\left(X \_1\right)$ as independent variables in this study simultaneously and partially have a positive and significant effect on employee performance.
\end{abstract}

Keywords: Influence, motivation, work, employee, performance

\begin{abstract}
Abstrak
Penelitian ini dilakukan dengan tujuan untuk mengetahui Sejauhmana pengaruh motivasi kerja secara simultan terhadap kinerja pegawai. Sejauhmana pengaruh motivasi kerja secara parsial terhadap kinerja pegawai. Jenis Penelitian ini adalah conclusive research yaitu menjawab suatu permasalahan yang memerlukan pemecahan dengan menggunakan pedekatan deskriptif kuantitatif. Teknik Analisis Data dengan Uji Validitas, Uji Reabilitas Instrumen, Analisis statistik Deskriptif, Uji Hipotesis, Uji Linearitas, Analisi Regresi linear Berganda. Motivasi kerja secara bersama-sama berpengaruh positif terhadap kinerja pegawai berdasarkan model Summary diatas bahwa koefisien $\mathrm{R}$ adalah $(0,730)$ dan nilai koefisien Adjusted R Square adalah 0,510 yang berarti bahwa ada penggaruh motivasi kerja adalah sebesar $(51 \%)$ dan sisanya (49\%) di pengaruhi oleh variabel lain yang tidak diteliti Untuk melihat apakah motivasi kerja pengaruh positif dan signifikan terhadap kinerja pegawai dapat dilihat bahwa nilai $f_{\text {hitung }}$ sebesar 23,531 lebih besar dari $f_{\text {tabel }}$ sebesar 2,75 yaitu 23,531> 2,75 dengan tingkat signifikansi sebesar 0,000. Motivasi kerja berpengaruh positif dan signifikan terhadap kinerja pegawai terlihat pada tabel coeffisien nilait $t_{\text {hitung }} 2,034$ lebih besar dari $t_{\text {tabel }}$ 1,99897dengan tingkat signifikan lebih kecil dari alpha $(0,046<0,05)$, maka Ho ditolak dan $\mathrm{H}_{\mathrm{a}}$ diterima Kesimpulan Variabel Motivasi $\left(X_{1}\right)$ sebagai variable bebas dalam penelitian ini secara simultan dan parsial berpengaruh positif dan signifikan terhadap kinerja pegawai.
\end{abstract}

Kata kunci: Pengaruh, motivasi, kerja, kinerja, pegawai

(C) 2020 Jurnal IJMB

Diterima Redaksi 16-05-2020 | Selesai Revisi : 30-05-2020 | Diterbitkan Online : 31-05-2020 


\section{Pendahuluan}

Manajemen adalah seni dan ilmu dalam perencanaan, pengorganisasian, pengarahaan, pemotivasian, dan Motivasi menyangkut perilaku manusia dan merupakan pengendalian terhadap orang dan mekanisme kerja untuk sebuah unsur yang vital dalam manajemen. Motivasi mencapai tujuan. Dikatakan manajemen sebagai suatu dapat didefinisikan sebagai membuat orang seni merupakan sebagai suatu keahlian, kemahiran, menyelesaikan pekerjaan dengan semangat, karena orang kemampuan, dan keterampilan dalam aplikasi ilmu itu ingin melakukanya. Tugas manajer adalah pengetahuan untuk mencapai tujuan. Sedangkan menciptakan kondisi-kondisi kerja yang akan dikatakan manajemen sebagai suatu ilmu merupakan membangkitkan dan memelihara keinginan yang akumulasi pengetahuan yang telah disistematiskan dan bersemangat ini [3].

diorganisasikan untuk mencaapai tujuaan kebenaran umum. kebutuhan manusia semakin hari semakin meningkat, bahkan relative tak terbatas baik berupa kebutuhan fisik, ekonomi, psikologis dan sosiologis, sehingga mendorong manusia untuk lebih meningkatkan produktivitas, kreatifitas dan inovasi.

Keberhasilan atau kegagalan suatu organisasi baik itu merupakan ukuran berapa lama seseorang dapat menjaga pemerintah maupun swasta dalam mencapai tujuanya usaha mereka. Individu yang termotivasi akan factor penentu adalah manusia dalam hal ini lebih kepada menjalankan tugas cukup lama untuk mencapai tujuan sumber daya manusia (SDM) yang meliputi moral, sprit, mereka" semangat, gairah, mental, sikap, pendidikan, lingkungan, pengalaman.

Abraham Maslow mengembangkan Hierarchy of Needs Theory dan mengelompokan motivasi ke dalam lima Suatu proses pengarahan dan pemberian fasilitas kerja tingkatan. (a) Kebutuhan (pshisiologis), (b). rasa aman kepada orang yang diorganisasikan dalam kelompok (safety), (c). Sosial (hubungan sosial), (d). Penghargaan formal untuk mencapai tujuan tujuan. Proses pengarahan (esteem), dan (e). aktualisasi diri (Self-actualization), dan menurut millet yaitu suatu rangkaian kegiatan untuk dicapai secara berjenjang. Hierarki maslow terutama memberikan petunjuk atau instruksi dari atasan kepada relevan di tempat pekerjaan karena individu tidak hanya bawahan dalam kelompok formal dan untuk mencapaai perlu uang dan reward, tetapi juga perlu kehormatan dan tujuan, dalam pemberian fasilitas kerja merupakan suatu interaksi. Ada beberapa cara perlu dilakukan untuk dapat rangkaian kegiatan untuk memberikan sarana dan membangun motivasi prasarana serta jasa yang memudahkan pelaksanaan pekerjaan dari seorang atasan kepada bawahan atau kepada orang dalam kelompok formal untuk mencapai tujuan [1]. kesimpulan pendapat diatas manajemen merupakan hal yang sangat penting didalam sebuah organisasi agar jelas petunjuk organisasi dalam pelaksanaan tugas masing-masing serta memudahkan pelaksanaan pekerjaan dari atasan kepada bawahaan untuk mencapai tujuan organisasi.

Selain itu berhasil tidaknya suatu organisasi dalam pencapaian tujuan dan target-target operasionalnya tidak lepas dari peran pegawai yang berkompeten dan berintegrasi tinggi. seberapa bagus program-program yang dibuat, tidak ada artinya tanpa sumber daya manusia yang berkualitas yang mengukir prestasi tinggi dalam setiap pelaksanaan kegiatan dan tugas yang diberikan kepadanya [2]. Untuk memperoleh sumber daya yang berkualitas tentu dibutuhkan iklim organisasi yang nyaman dan kondusif, dengan iklim organisasi yang menyenangkan setiap pegawai dapat bekerja dengan baik dan menyelesaikan tugasnya dengan kinerja yang tinggi.

perusahaan, karyawan, dan masyarakat". Artinya sebuah organisasi akan berjalan dengan baik jika manager mampu mengelola sumberdaya manusia yang ada dalam organisasinya dengan baik, maka managerlah yang memegang kendali dalam mewujudkan efektifitas
Menjadi manajer yang baik Seorang manajer yang baik mempunyai karakteristik (a). mempunyai komitmen untuk bekerja, (b). melakukan kolaborasi dengan bawahanya, (c). memercayai orang, (d). loyal pada teman sekerja, (e). menghindari politik kantor. Memperbaiki Komunikasi Komunikasi antara manajer dengan bawahan dilakukan dengan menyediakan informasi secara akurat dan detail secepat mungkin. Informasi menyangkut apa yang ingin diberitahukan manajer maupun apa yang ingin mereka ketahui.

Menciptakan Budaya Tidak Menyalahkan Setiap orang yang mempunyai tanggung jawab harus dapat menerima kegagalan. Tetapi untuk memotivasi secara efektif perlu dibudayakan tidak menyalahkan. Kesalahan harus dikenal dan kemudian menggunakanya untuk memperbaiki kesempatan keberhasilan dimasa yang akan datang. Pendekatan-pendekatan dasar terhadap motivasi berbeda-beda dikalangan manajer [4]

Terdapat tiga pendekatan-pendekatan umum yang dipilih adalah (a). Lingkungan (b). Produtivitas (c). Pemuasan kebutuhan". Asumsinya adalah bahwa pegawai yang khas akan melaksanakan paling baik jika diberikan lingkungan yang menyenangkan. Karena itu, untuk memotivasikan pertimbangan-pertimbangan pribadi dan 
ramah diperluas sampai kepada pegawai dan kondisi pekerjaan yang menyenangkan pun perlu diadakan.

Pegawai merupakan sumber daya manusia yang pada dasarnya merupakan bagian dari organisasi, artinya sebagai anggota organisasi, pegawai hendaknya secara efektif ikut serta memajukan organisasi, memberikan nilai tambah pada organisasi dalam setiap aspek sesuai dengan kemampuan dan kompetensinya. Berhasil tidaknya suatu perusahaan atau organisasi dalam pencapaian tujuan dan target-target operasionalnya tidak lepas dari peran pegawai yang berkompeten dan berintegrasi tinggi.

Keberhasilan suatu organisasi sangat tergantung pada sumberdaya manusianya, seberapa bagus programprogram yang dibuat, tidak ada artinya tampa sumberdaya yang berkualitas yang mengukir prestasi tinggi dalam setiap pelaksanaan kegiatan dan tugas yang diberikan kepadanya. Untuk memperoleh sumberdaya yang berkualitas tentu dibutuhkan iklim organisasi yang nyaman dan kondusif, dengan iklim organisasi yang menyenangkan setiap pegawai dapat bekerja dengan baik dan menyelesaikan tugasnya dengan kinerja yang tinggi. Disamping itu, untuk mencapai tujuan organisasi perlu diupayakan langkah-langkah yang terencana, sistematik, berkelanjutan, dan terkoordinasi dalam meningkatkan kualitas dan pengabdian pegawai.

Pegawai merupakan aset terpenting dari sebuah organisasi kamajuan organisasi akan terletak pada bagaimana pegawai mampu melaksanakan pekerjaan dengan penuh tanggung jawab, agar semua itu terjaga maka pimpinan harus mampu memberikan motivasi yang kepada bawahanya dalam bentuk a.Kebutuhan (pshisiologis), (b). rasa aman (safety), (c). Sosial (hubungan sosial), (d). Penghargaan (esteem), dan (e). aktualisasi diri (Self-actualization, jika pegawai sudah merasa terpenuhi kebutuhannya maka pegawai itu akan memberikan loyalitas dan kinerja yang tinggi kepada organisasi atau perusahaan tempat berkerja.

Kinerja merupakan suatu fungsi dari motivasi dan kemampuan untuk menyelesaikan tugas/pekerjaan. Karyawan sepatutnya memiliki derajat willingness (kesediaan) dan tingkat capacity (kemampuan) tertentu. Kesediaan dan keterampilan tidaklah cukup efektif untuk mengerjakan sesuatu tanpa pemahaman yang jelas tentang apa yang akan dikerjakan dan bagaimana mengerjakannya. Kinerja merupakan perilaku nyata yang ditampilkan setiap karyawan sebagai prestasi kerja yang dihasilkan sesuai perannya dalam perusahaan.

Tidak mudah untuk menilai kinerja karyawan secara akurat. Sifat maupun cara penilaian kinerja bergantung pada bagaimana SDM dipandang dan diperlakukan di dalam perusahaan a. Jika perusahaan berpegang pada asumsi bahwa orang tidak akan bekerja kecuali jika mereka diawasi dan dikendalikan dengan ketat, maka perusahaan cenderung menerapkan cara penilaian yang berifat rahasia dan biasanya penilaian cenderung bersifat tidak obyektif. Oileh karena itu laporan tentang kinerja karyawan pun merupakan laporan yang bersifat rahasia pula. b Jika perusahaan mempunyai pandangan bahwa setiap individu akan bekerja sesuai dengan potensi dan kekuatan-kekuatannya dan bahwa kemampuan manusia dapat ditambah/dikembangkan, maka perusahaan akan mengusahakan suatu sistem penilaian yang berusaha mengenali, memperjelas, mengembangkan, dan memanfaatkan potensi dan kemampuan karyawan.

Yang mempengaruhi kinerja sebagai berikut a. Efektifitas dan efisiensi. Bila suatu tujuan tertentu akhirnya bisa dicapai, kita boleh mengatakan bahwa kegiatan tersebut efektif tetapi apabila akibat-akibat yang tidak dicari kegiatan menilai yang penting dari hasil yang dicapai sehingga mengakibatkan kepuasan walaupun efektif dinamakan tidak efesien. b. Otoritas (wewenang) Otoritas menurut adalah sifat dari suatu komunikasi atau perintah dalam suatu organisasi formal yang dimiliki seorang anggota organisasi kepada anggota yang lain untuk melakukan suatu kegiatan kerja sesuai dengan kontribusinya. Perintah tersebut mengatakan apa yang boleh dilakukan dan yang tidak boleh dalam organisasi tersebut. c Disiplin Disiplin adalah taat kepda hukum dan peraturan yang berlaku Jadi, disiplin karyawan adalah kegiatan karyawan yang bersangkutan dalam menghormati perjanjian kerja dengan organisasi dimana dia bekerja.d. Inisiatif yaitu berkaitan dengan daya pikir dan kreatifitas dalam membentuk ide untuk merencanakan sesuatu yang berkaitan dengan tujuan organisasi

Agar tercapainya tujuan dari organisasi maka seorang manager harus memiliki manajemen yang baik dalam menjalin hubungan dengan para pegawainya terutama dalam hal komunikasi sehingga para pegawai merasa nyaman dalam berkerja, sealain itu seorang manejer juga harus memperhatikan kesejahteraan para pegawai dalam bentuk pemberian kompensasi dengan cara melakukan penilaian terhadap kenirja pegawai agar pegawai terpacu untuk memberikan hal yang terbaik bagi organisasi serta akan menunjukan loyalitas dan tanggung jawab terhadap pekerjaan yang diberikan.

Selain yang tersebut diatas ada beberapa karakteristik orang yang mempunyai kinerja tinggi adalah sebagai berikut: 1 . Memiliki tanggung jawab pribadi yang tinggi. 2. Berani mengambil dan menanggung resiko yang dihadapi. 3. Memiliki tujuan yang realistis. 4. Memiliki rencana kerja yang menyeluruh dan berjuang untuk merealisasi tujuannya. 5. Memanfaatkan umpan balik (feed back) yang konkrit dalam seluruh kegiatan kerja yang dilakukannya. 6. Mencari kesempatan untuk merealisasikan rencana yang telah diprogramkan. Maka dapat disimpulkan jika kinerja pegawai yang akan melakukan pekerjaan dengan penuh tanggung jawab serta tau dengan resiko yang akan dihadapi dan yang terpenting memiliki tujuan yang raelitis kedepan dengan apa yang akan dicapai untuk kemajuan dirinya dan organisasinya. 
Penelitian Lia Fauziah [5] Fakultas Ekonomi, Dian menjelaskan pengaruh variable bebas terhadap variabel Nuswantoro universitas Semarang 2013 tentang terikat Dalam penelitian ini data yang digunakan adalah Pengaruh Motivasi, Pelatihan Dan Kompensasi data primer dan data sekunder. Data primeradalah data Terhadap Kinerja Karyawan PT. Nadira Prima Semarang yang dikumpulkan langsung oleh peneliti dari responden

Hasil penelitian menunjukkan nilai $\mathrm{t}$ hitung motivasi kerja sebesar 26,010 > t Tabel $(1,9855)$ dan nilai signifikansi sebesar $0,000<0,05$ maka H1 diterima, artinya terdapat pengaruh antara motivasi kerja terhadap kinerja karyawan, nilai t hitung pelatihan sebesar 23,154 $>\mathrm{t}$ Tabel $(1,9855)$ dan nilai signifikansi sebesar $0,000<$ 0,05 maka $\mathrm{H} 2$ diterima, artinya terdapat pengaruh antara pelatihan terhadap kinerja karyawan, nilai $\mathrm{t}$ hitung kompensasi sebesar 19,137 > t Tabel $(1,9855)$ dan nilai signifikansi sebesar $0,000<0,05$ maka H2 diterima, artinya terdapat pengaruh antara kompensasi terhadap kinerja karyawan.Selain itu, hasil uji $\mathrm{F}$ menunjukkan bahwa bahwa motivasi kerja (X1), pelatihan (X2) dan kompensasi (X3) berpengaruh secara bersama-sama terhadap kinerja karyawan. Hal ini ditunjukkan dengan signifikansi F hitung sebesar 1068,510 > F Tabel $(2,71)$ dan signifikansi Fsebesar 0,000 $<0,05$.

Penelitian Musriha [6] tentang Pengaruh Budaya Organisasi, Pelatihan, Kompensasi dan MotivasiKerja, terhadap Kinerja Pegawai di Departemen Perindustrian danPerdagangan Kabupaten Probolinggo. Berdasarkan hasil hipotesis pertama dapat diketahuibahwa hipotesis yang diajukan yaitu Budaya Organisasi(X 1), Pelatihan (X2), Kompensasi (X 3) dan Motivasi (X4)secara serempak mempunyai pengaruh signifikan terhadapKinerja diterima kebenarannya hal ini dibuktikan denganuji signifikasi atau Uji $\mathrm{F}$ pengaruh serempak variabel bebasterhadap variabel terikatnya adalah signifikan karena nilaiP Sig sebesar 0.000 lebih kecil dari 0.05.Berdasarkan hasil hipotesis kedua dapat diketahuibahwa hipotesis yang diajukan yaitu Budaya Organisasi(X 1), Pelatihan (X2), Kompensasi (X 3), dan Motivasi (X4)secara parsial berpengaruh signifikan terhadap Kinerjakarena memiliki nilai P Sig di bawah 0.05, Berdasarkanuji hipotesis secara parsial dapat diketahui bahwa hipotesisyang ketiga yang diajukan yaitu Kompensasi mempunyaipengaruh yang dominan terhadap kinerja pegawai dapatditerima kebenarannya karena pengaruhnya lebih besar biladibandingkan dengan pengaruh variabel yang lain yaitusebesar 0.554.

Dari 2 penelitian terdahulu diatas dapat dilihat bahwa terdapat pengaruh motivasi terhadap kinerja karyawan baik secara bersama-sama dan secara parsial, kinerja karyawan juga dipengaruhui oleh faktor lain selain motivasi seperti pelatihan, kompensasi, budaya organisasi dan lain-lainya.

\section{Metode Penelitian}

Jenis Penelitian yang digunakan adalah conclusive research yaitu menjawab suatu permasalahan yang memerlukan pemecahan dengan menggunakan pedekatan deskriptif kuantitatif. Penelitian ini berusaha tempat penelitian, sedangkan data sekunder adalah data yang diperoleh dari studi kepustakaan seperti dari bukubuku, jurnal, laporan [7].

Instrumen penelitian ini berupa kuesioner penelitian yang diajukan kepada para responden yaitu dosen dan staf universitas dharmas indonesia. Natinya jawaban dari para responden masih bersifat kualitatif kemudian akan di ukur secara kuantitatif dengan menggunakan skala likert $1 \mathrm{~s} / \mathrm{d} 5$ dengan kriteria sebagai berikut : 1.Sangat Setuju (SS) 2. Setuju (S) 3. Cukup Setuju (CS) 4.Tidak Setuju (TS) 5.Sangat Tidak Setuju (STS) Tingkat capaian responden (TCR) dihitung dengan menggunakanFormula $\mathrm{TCR}=\left(\mathrm{R}_{\mathrm{s}} / \mathrm{n}\right) \mathrm{X} 100 \%$, dimana TCR merupakan Tingkat capaian responden, Rs adalah Rata-rata skor jawaban responden, dan $\mathrm{n}$ merupakan Jumlah skor maksimum

Tabel. 1. Kisi-kisi Instrumen Penelitian

\begin{tabular}{llll}
\hline variabel & indikator & No soal & Jumlah soal \\
\hline Motivasi & fisiologi & 123 & 3 \\
\hline & penghargaan & 456 & 3 \\
\hline & aktualisasi & 78910 & 4 \\
\hline
\end{tabular}

\section{Populasi dan Sampel}

Menurut Masngundi Populasi adalah keseluruhan objek penelitian yang akan dapat terdiri dari manusia, bendabenda, hewan, tumbuhan, gejala-gejala, nilai test atau peristiwa sebagai sumber data data yang memiliki karakteristik tertentu di dalam suatu penelitian. Sampel adalah proses pemilihan sejumlah elemen dari populasi yang mencukupi dan dapat mewakili populasi tersebut Sampel juga merupakan bahagian dari populasi yang akan mewakili kerakteristik populasi [8].

Kinerja Menurut FX, Soejadi [9] Kinerja adalah hasil kerja yang dapat dicapai oleh seseorang atau sekelompok orang dalam organisasi, sesuai dengan wewenang dan tanggung jawab masing-masing dalam rangka mencapai tujuan organisasi yang dilakukan secara legal Dalam penelitian ini kinerja pegawai disebut sebagai variabel (Y).

Motivasi sebagai proses psikologis timbul diakibatkan oleh hal yang ada dalam diri seorang itu sendiri yang disebut (intrinsic) seperti kebutuhan, sikap, pengalaman, pendidikan, cita-cita yang menunjang dll atau yang dipengaruhi hal dari luar seorang tersebut (ekstrinsik) seperti pemimpin, peraturan, teman kerja dll. Dalam penelitian ini disebut variabel bebas (X1) 
Teknik Analisis Data

Uji Validitas

Menurut Sugiyono [7] validitas adalah instrumen diuji dengan cara membandingkan (untuk mencari kesamaan) antara kriteria yang ada pada instrumen dengan faktafakta empiris yang terjadi dilapangan. Instrumen penelitian yang mempunyai validitas eksternal yang tinggi akan mengakibatkan hasil penelitian yang tinggi pula dengan teknik korelasi product moment dengan rumus

$\mathrm{ri}=\frac{n \sum x y-\left(\sum x\right)-\left(\sum y\right)}{\left.\sqrt{\left(n \sum x^{2}\right.}-\sum x^{2}\right)\left(n \sum y^{2}-\left(\sum y^{2}\right)\right.}$

(1)

$\mathrm{n}=$ Jumlah responde,

$\mathrm{X}=$ Skor total tiap item,

$\mathrm{Y}=$ Skor total

Uji Reabilitas Instrumen

Dengan analisis reliabilitas dapat 1). Memudahkan bagaimana butir-butir pertanyaan dalam kuesioner saling berhubungan. 2). Mendapatkan nilai alpha cronbach's yang merupakan indeks internal consistency dari skala pengukuran secara keseluruhan, 3). Mengdentifikasi butir-butir pertanyaan dalam kuesioner yang bermasalah dan harus direvisi atau harus dihilangkan [10]. Dalam penelitian ini uji reabilitas data menggunakan "alpha cronbach.

\section{Analisis statistik Deskriptif}

Analisis statistik deskriptif adalah statistic yang berfungsi untuk mendiskripsikan atau member gambaran terhadap obyek yang diteliti melalui data sampel atau populasi sebagaimana adanya, tanpa melakukan analisis dan membuat kesimpulan yang berlaku untuk umum.

Uji Hipotesis

Untuk menguji hipotesis maka digunakan uji $\mathrm{F}$ ratio untuk membuktikan tingkat keberartian variabel bebas terhadap variabel terikat.dengan rumus sebagai berikut:

$$
F=\frac{R^{2} / K}{\left(1-R^{2}\right)(n-K-1)}
$$

\section{Dimana:}

$\mathrm{K}=$ Banyaknya variabel bebas

$\mathrm{n}=$ Banyaknya anggota sampel

$\mathrm{R}=$ Koefisien korelasi ganda.

Untuk menentukan hipotesis (Ha) diterima atau ditolak, maka digunakan asumsi sebagai berikut: Jika nilai signifikan hasil uji regresi linear berganda lebih kecil dari< 0,05, maka variabel bebas atau independenmemiliki pengaruh positif dan signifikan terhadap kinerja. Jika nilai signifikan hasil uji regresi linear berganda lebih besar dari >0,05, maka variabel bebas atau independen tidak memiliki pengaruh yang signifikan terhadap kinerja.

\section{Hasil dan Pembahasan}

Analisis Deskriptif Variabel Penelitian

Setelah dilakukan pengumpula data terhadap hasil kuisioner yang disebarkan kepada responden yang dijadikan sampel maka telah diperoleh nilai dari responden terhadap tiap-tiap butir pernyataan pada variable motivasi kerja $(x)$ dan kinerja ( $Y$ )yang diberikan disajikan dalam bentuk tabel distribusi frekuensi dibawah ini :

Tabel. 2. Distribusi Frekuensi Jawaban Responden Terhadap Pernyataan Variabel Motivasi Kerja $\left(\mathrm{X}_{1}\right)$

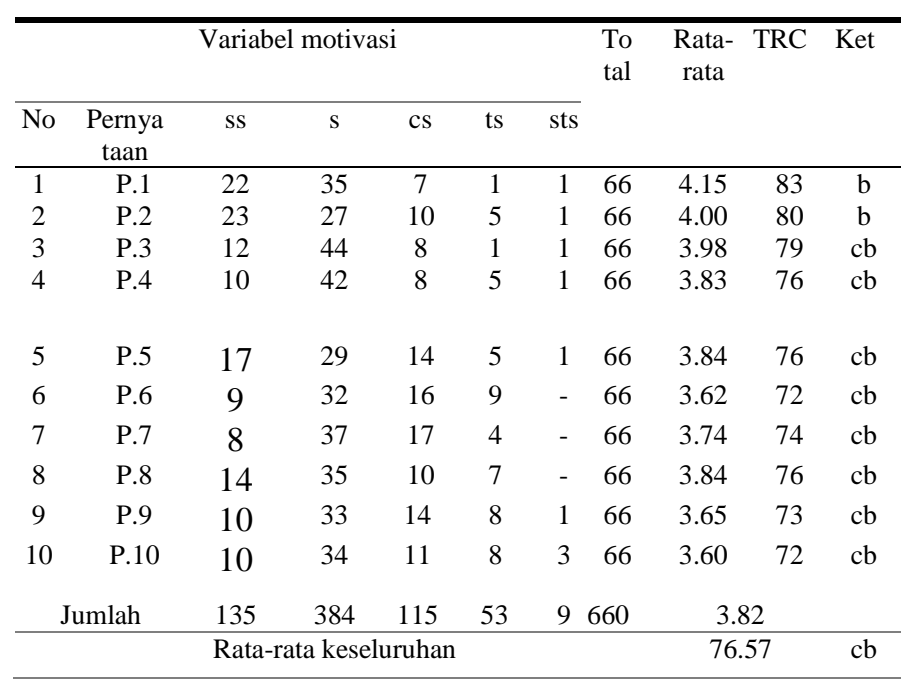

Berdasarkan distribusi frekuensi variabel Motivasi kerja dapat dilihat bahwa jawaban responden penelitian mayoritas memberikan jawaban kategori " Setuju”. Dengan jumlah nilai 348 dan nilai rata-rata sebesar $76.57 \%$ sudah dikategorikan bahwa intrumen sudah cukup baik.

Tabel. 3. Distribusi Frekuensi Jawaban Responden Terhadap Pernyataan Variabel kinerja (Y)

\begin{tabular}{|c|c|c|c|c|c|c|c|c|c|}
\hline & & Var & $1 \mathrm{Kin}$ & & & & Total & Rata- & TRC \\
\hline No & $\begin{array}{c}\text { Pernya } \\
\text { taan }\end{array}$ & Ss & $S$ & Cs & Ts & Sts & & & \\
\hline 1 & P.1 & 27 & 33 & 6 & - & - & 66 & 4.31 & 86 \\
\hline 2 & P.1 & 24 & 24 & 12 & 6 & - & 66 & 4.00 & 80 \\
\hline 3 & P. 3 & 4 & 38 & 19 & - & 5 & 66 & 3.54 & 70 \\
\hline 4 & P.4 & 20 & 27 & 12 & 7 & - & 66 & 3.90 & 78 \\
\hline 5 & P. 5 & 23 & 10 & 27 & 4 & 2 & 66 & 3.72 & 74 \\
\hline 6 & P.6 & 18 & 28 & 20 & - & - & 66 & 3.96 & 79 \\
\hline 7 & P.7 & 20 & 23 & 23 & - & - & 66 & 3.95 & 79 \\
\hline 8 & P.8 & 18 & 18 & 27 & 18 & 3 & 66 & 3.77 & 75 \\
\hline 9 & P.9 & 16 & 30 & 14 & 5 & 1 & 66 & 3.83 & 76 \\
\hline 10 & P.10 & 28 & 29 & 6 & 2 & 1 & 66 & 4.22 & 84 \\
\hline & umlah & 198 & 260 & 166 & 27 & 9 & 660 & & \\
\hline
\end{tabular}

Berdasarkan distribusi frekuensi variabel kinerja dapat dilihat bahwa jawaban responden penelitian mayoritas memberikan jawaban kategori " Setuju”. Dengan jumlah nilai 260 dan nilai rata-rata sebesar $78.51 \%$ dikategorikan bahwa intrumen sudah cukup baik. 
Uji Validitas

Uji validitas dilakukan pada seluruh butir pernyataan dalam instrument dengan cara mengkorelasikan skor tiap-tiap butir pernyataan dengan skor total.data diolah dengan bantuan SPSS For Windows 22.00. Dari hasil uji validitas dapat diketahui bahwa seluruh item pernyataan valid dan berkorelasi dengan taraf signifikan 0,05 dapat dilihat pada tabel 4 .

Tabel. 4. Hasil uji validitas motivasi kerja

\begin{tabular}{ccccc}
\hline No & Item Peryataan & Nilai $\mathrm{r}_{\mathrm{xy}}$ & Nilai $\mathrm{r}_{\text {tabel }}$ & Keterangan \\
\hline 1 & Pernyataan 1 & .641 & 0,242 & Valid \\
2 & Pernyataan 2 & .657 & 0,242 & Valid \\
3 & Pernyataan 3 & .607 & 0,242 & Valid \\
4 & Pernyataan 4 & .704 & 0,242 & Valid \\
5 & Pernyataan 5 & .756 & 0,242 & Valid \\
6 & Pernyataan 6 & .668 & 0,242 & Valid \\
7 & Pernyataan 7 & .620 & 0,242 & Valid \\
8 & Pernyataan 8 & .680 & 0,242 & Valid \\
9 & Pernyataan 9 & .695 & 0,242 & Valid \\
10 & Pernyataan 10 & .661 & 0,242 & Valid \\
\hline
\end{tabular}

Berdasarkan analisis pada table diatas dapat dijelaskan bahwa dari 10 instrument pernyataan yang mengukur variable motivasi kerja (X1) dinyatakan valid semua karena Nilai $\mathbf{r}_{\mathbf{x y}}>$ Nilai $\mathbf{r}_{\text {tabel }}$

Tabel. 5. Hasil Uji Validitas Kinerja Pegawai (Y)

\begin{tabular}{ccccc}
\hline No & Item Peryataan & Nilai $\mathrm{r}_{\mathrm{xy}}$ & Nilai $\mathrm{r}_{\text {tabel }}$ & Keterangan \\
\hline 1 & Pernyataan 1 & .625 & 0,242 & Valid \\
2 & Pernyataan 2 & .511 & 0,242 & Valid \\
3 & Pernyataan 3 & .315 & 0,242 & Valid \\
4 & Pernyataan 4 & .519 & 0,242 & Valid \\
5 & Pernyataan 5 & .645 & 0,242 & Valid \\
6 & Pernyataan 6 & .488 & 0,242 & Valid \\
7 & Pernyataan 7 & .482 & 0,242 & Valid \\
8 & Pernyataan 8 & .691 & 0,242 & Valid \\
9 & Pernyataan 9 & $.327 \mathrm{~s}$ & 0,242 & Valid \\
10 & Pernyataan 10 & .322 & 0,242 & Valid \\
& & & & \\
\hline
\end{tabular}

Tabel. 6. Reliability Statistics

\begin{tabular}{cccc}
\hline Variabel & $\alpha$ (alpha) & $\alpha$ standar & Ket \\
\hline $\mathrm{X}_{1}=$ Motivasi & .763 & 0,060 & Reliabel \\
\hline
\end{tabular}

Tabel 6 menunjukkan bahwa nilai cronbach alpha untuk variabel yang ada adalah $\mathrm{X}_{1}(0,763)$ dan $\mathrm{Y}(0,710)$. Indikator untuk uji reliabilitas adalah croanbach's alpha. Apabila nilai croanbach's alpha $>0,6$ menunjukkan semua instrumen yang digunakanreliable atau handal

Analisis statistik Deskriptif

Analisis Deskriptif digunakan untuk menjelaskan karakteristik responden penelitian. Dalam analisa ini dipaparkan untuk responden berdasarkan jenis kelamin, usia, pendidikan dan masa kerja pegawai

Dari instrumen yang disebarkan kepada 66 orang pegawai diperoleh data yang dapat digunakan untuk menguji hipotesis yang diajukan dalam penelitian ini. Data yang diperoleh diolah dengan SPSS versi 22,0 dengan alat analisis regesi linear berganda. signifikan terhadap kinerja pegawai maka hipotesis pertama artinya diterima.

Hipotesis kedua bahwa motivasi kerja berpengaruh positif dan signifikan terhadap kinerja pegawai. tabel coeffisien di atas terlihat nilait hitung $_{2,034}$ lebih besar dari $t_{\text {tabel }} 1,99897$ dengan tingkat signifikan lebih kecil dari alpha $(0,046<0,05)$, maka Ho ditolak dan $\mathrm{H}_{\mathrm{a}}$ diterima. Artinya, secara parsial ada pengaruh yang positif dan signifikanvariabel motivasi kerja $\left(\mathrm{X}_{2}\right)$ terhadap kinerja pegawai $(\mathrm{Y})$. Oleh karena itu hipotesis kedua yang menyatakan "motivasi kerja secara parsial berpengaruh positif dan signifikan terhadap kinerja pegawai universitas dharmas indonesia " diterima. Dengan koefisien regresi bertanda positif 0,133 menunjukkan terjadinya hubungan yang positif dan signifikan dari motivasi kerja terhadap kinerja pegawai. Hal ini bermakna motivasi dalam berkerja sangat penting untuk bagi seluruh pegawai seluruh pegawai akan Berdasarkan analisis pada table diatas dapat dijelaskan semakin tinggi pula kinerja seluruh pegawai.

bahwa dari 10 instrument pernyataan yang mengukur variable kinerja pegawai (Y)dinyatakan validsemua 4. Kesimpulan.

karena Nilai $\mathbf{r}_{\mathbf{x y}}>$ Nilai $\mathbf{r}_{\text {tabel }}$

Uji Reliability

Reliabel artinya dapat dipercaya juga dapat diandalkan. Suatu instrumen dapat dipercaya untuk digunakan sebagai alat pengumpul data karena instrumen tersebut sudah dianggap baik Pengujian reliabilitas dapat dilihat pada tabel dibawah 6

Variabel motivasi sebagai variabel bebas dalam penelitian ini memiliki pengaruh positif dansignifikan terhadap kinerja pegawai sebagai variabel terikat dengan memberikan kontribusi sebesar 51\%, sedangkan $49 \%$ dipengaruhui oleh variabel lain yang tidak termasuk kedalam ruang lingkup penelitian ini. Dalam upaya mencapai kenierja pegawai yang sangat baik maka faktor motivasi dan faktor lain selain motivasi juga perlu diperhatikan oleh organisasi/instusi, Berhasil tidaknya suatu organisasi/institusi dalam pencapaian visi, misi dan tujuan organisasi/institusi tidak lepas dari peran pegawai yang berkompeten dan berintegrasi tinggi. 
Kelik Purwanto

International Journal of Management and Business (IJMB) Vol.1 No.1 (2020) 31-36

\section{Daftar Rujukan}

[1] Anwar Prabu Mangkunegara, Manajemen Sumber Daya [7] Manusia. Bandung: Rosda Karya, 2002.

[2] W. Sampurno, Pengantar Manajemen Bisnis. Jakarta: Politeknik [8] Telkom, 2019.

[3] D. wibowo,prof, manajemen kinerja. Jakarta: PT raja grafindo [9] persada, 2012

[4] George R. Terry \& Leslie W. Rue, Dasar-Dasar Manajemen. Jakarta: Bumi aksara, 2015.

[5] L. Fauziah, "Pengaruh Motivasi, Pelatihan dan Kompensasi Terhadap Kinerja Karyawan PT. Nadira Prima Semarang,” 2013.

[6] Musriha, "Pengaruh Budaya Organisasi, Pelatihan, Kompensasi dan Motivasi Kerja, terhadap Kinerja Pegawai di Departemen
Perindustrian dan Perdagangan Kabupaten Probolinggo," $J$ Ekon., vol. 6, no. 1, pp. 1-8, 2013.

Sugiyono.Prof.DR, Statistik Untuk Penelitian. bandung: Alfabeta., 2013.

D. H. Masngundi, Prof, Buku Metodologi Penelitian. Jakarta: Trianandra Universiti Press, 2012.

Arfizal., "Pengaruh Komitmen Organisasi Dan Kepuasan Kerja Terhadap Kinerja Pegawai Pada Dinas Sosial Tenaga Kerja dan Transmigrasi Kabupaten Sijunjung."

[10] S. Arikunto, Prosedur Penelitian Suatu Pendekatan Praktik. Jakarta: Rineka Cipta, 2010. 